\title{
ANTI-DISCRIMINATION INEMPLOYMENT REGULATION FOR PERSONS WITH DISABILITIES IN INDONESIA
}

\author{
Imma Indra Dewi W \\ Faculty of Law, Atma Jaya Yogyakarta University \\ E-mail: mbakyuimma@gmail.com
}

\begin{abstract}
Anti-discrimination is known as equal opportunity and treatment which is the right of every citizen in each aspects of life. The principles of anti-discrimination must be included in every product of legislation, including the employment regulation for persons with disabilities in Indonesia. Anti-discrimination in employment regulation for persons with disabilities have been included in the Indonesian constitution. In addition, it has also been adopted in various articles on legislation, regulating about employment for persons with disabilities, namely Law Number 3 of 2013, Law Number 19 of 2011 and LawNumber 8 of 2016. In substance, the law that guarantees the rights of persons with disabili ties in a number of laws and regulations in Indonesia is sufficient. However, the regulation in Law Number 13 of 2003 aboutlabor law is not yet clear. Adjustmentsneed to be made on Law Number 13 of 2003, Law Number 19 of 2011, and Law Number 8 of 2016. The need for the many provisions of labor laws that have not been implemented requires affirmative action to realize equal opportunities in all aspects of life and livelihood for persons with disabilities.
\end{abstract}

Key words: Anti-discrimination, regulations, employment, labor, persons with disabilities,

\section{A. INTRODUCTION}

In the Law on Human Rights, discriminationis described as any directly or indirectly limitation, harassment, orexclusion based on the differentiation of people on the basis of religion, ethnicity, race, ethnicity, group, class, social status, economic status, gender, language, political beliefs causing the reduction, deviation or elimination of the recognition, implementation or use of human rights and basic freedoms in both individual and collective life in the political, economic, legal, social, cultural and other aspects of life. It is as stated in Article 1 number 3 of Law Number 3 of 9 1999. Thus, everyone though born with the physical differences such as skin color, hair, eyes and others continued to have such rights. This right also can not be revoked by anyone. This right is inherent in humans as human beings. (Rhona K. Smith, 2008:269)

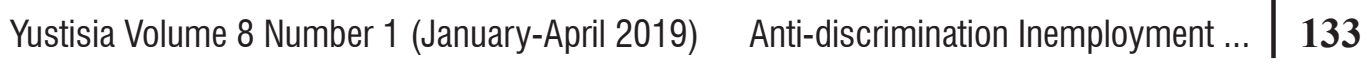

(C)2019; This is an Open Acces Research distributed under the term of the Creative Commons Attribution Licencee (https://Creativecommons.org/licences/by/4.0), which permits unrestricted use, distribution, and reproduction in any medium, provided the original works is properly cited. 
Anti-discrimination is known as equal opportunity and treatment which is the right of every citizen in every aspects of life, such as areas of economy, social, cultural, political and employment. Basically the principles of antidiscrimination according to Nursyahbani Katjasungkanashould be included in every product of legislation. (Nurjannah S, 2013:33)

Article 28D paragraph (2) of the 1945 Constitution of the Republic of Indonesia states that every person has the right to work and to receive compensation and fair and proper treatment in work relations. Law Number 39 of 1999 on the Human Rights also provides for anti-discrimination in terms of employment. Broadly speaking, the regulation stated that citizen has the right to work according to their talent, skills, and abilities. In addition, they are also free to choose their preferred job and also entitled to fair employment conditions.

Indonesia has Law Number 13 of 2003 that specifically provides protection for parties in the employment fields. Relating to anti-discrimination. Law Number 13 of 2003 regulates the equality of opportunities without discrimination to obtain employment for everyone. It also regulates that every worker gets equal treatment without discrimination from their employers.

Appointment of subject in these various regulations includes the regulation for persons with disabilities. Thus persons with disabilities are also entitled to antidiscrimination treatment in the field of employment. These provisions are in line with the principles of Law Number 8 of 2016 on the Persons with Disabilities. In the implementations and fulfilment of the rights of persons with disabilities, which are free from discrimination. Persons with disabilities are also entitled to the job held by the government, local governments, or private sectors without discrimination.

As a form of legal protection for the human rights fulfilment in Indonesia, especially for the right to obtain decent work forpersons with disabilities, Indonesia must have a fair and decisive set of legal regulations in place, state apparatus that is swift and pro-disabled, and a society that is inclusive of disability issues.(Jazim Hamidi, 2016:661). This gave birth to a special policy (affirmative action) as stipulated in Article 41 paragraph (2) of Law Number 39 of 1999 which determine every person with disabilities, elderly people, pregnant women and children have the right to obtain facilities and special treatment.

Based on this provision, persons with disabilities are also entitled to get jobs according to their level of disability. The fact is that even though it has been regulated in law, there are still many persons with disabilities who have not been included in formal sector employment, they even experienced discrimination.

It is estimated that there are 650 million persons with disabilities or $10 \%$ of the total population in the world. (United Nation Human Right, 2010:7) The ILO states that around $15 \%$ of the world's population or more than one billion people are disabled 
and is considered the largest minority group in the world. Average of $82 \%$ of persons with disabilities are in developing countries and live below the poverty line and often face limited access to proper health facilities, education, training and jobs. Persons with disabilities are relatively more vulnerable to poverty in each country, it can be measured both by traditional economic indicators such as GDP or, more broadly, in the non-financial aspects such as the monetary standard of living, such as education, health and living conditions. (http://www.ilo.org/wcmsp5/groups/public/---asia/--ro-bangkok/---ilo-jakarta/documents/publication/wcms_233426.pdf)

Those data above show that in fact persons with disabilities still don't get the same opportunity as compared to people without disabilities to work especially in the formal sector. Although, Indonesia has a specific disability protection norm stipulated in Law Number 8 of 2016 on Persons with Disabilities. This law is expected to be able to guarantee the rights of persons with disabilities. In addition to Law Number 8 of 2016 the right to work for persons with disabilities is also regulated in Law Number 13 of 2003 concerning Labor.

\section{B. PROBLEM STATEMENT}

Based on the description above the problem is what are the principles of antidiscrimination for persons with disabilities in the employment sector?

\section{RESEARCH METHOD}

The research is a normative legal research (doctrinal research). It used a qualitative analysis and legislation, case, as well as conceptual approaches. Thus, the choice of relevant material and integrated interpretation during interviews with stakeholders related to the main research issues.

\section{DISCUSSION AND RESEARCH RESULT}

\section{Discrimination in Employment Sector against Persons with Disabilities in} Indonesia

Persons with disabilities according to Article 1 number 1 of Law Number 8 of 2016 concerning Persons with Disabilities are those who experience physical, intellectual, mental, and/or sensory limitations for a long period of time whom interaction with the environment can experience obstacles and difficulties to participate fully and effectively with other citizens based on equal rights. This definition in the constitution regarding Persons with Disabilities is as regulated in the Convention on the Rights of Persons with Disabilities.

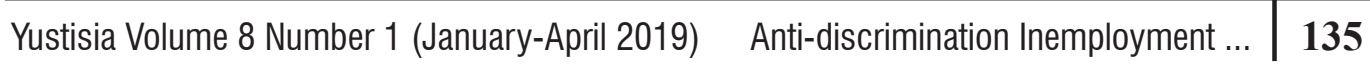


In Article 4 of Law Number 8 of 2016 it is regulated that the variety of persons with disabilities includes:

Persons with physical disabilities are persons with disrupted movement functions, including amputation, paralysis or stiffness, celebral palsy (CP), due to stroke, due to leprosy, and small people;

a. Persons with intellectual disabilities are persons with disrupted thought function due to below average level of intelligence, including slow learning, chronic disability and down syndrome;

b. Persons with mental disabilities are persons with disrupted thought, emotional and behavioral functions, including:

1) psychosocial, for instance schizophrenia, bipolar, depression, anxiety, and personality disorders;

2) developmental disability that affects the ability of social interactions including autism and hyperactivity

c. Persons with sensory disability are persons with disrupted one of the five sensory functions, including sight disability, hearing impairment, and/or speech disability.

The variety of Persons with Disabilities can be experienced in a single, multiple, or multi-year manner over a long period of time determined by medical personnel in accordance with the provisions of the legislation. Persons with multiple disabilities are persons who have two or more different types of disabilities, including speech, sight, or hearing disability. While the long term disability is defined as at least 6 (six) months long and/or permanent.

The World Health Organization (WHO) provides a definition of disability as a condition of limited ability to carry out activities within the limits that are considered normal. WHO divides disabilities into three categories, namely: (a) impairments, conditions ofabnormality or loss ofpsychological structure or function, or anatomic; (b) disability, inability or limitations as a result of impairment to carry out activities in a manner that is considered normal for humans; (c) handicap, a condition that is detrimental to a person due to impairment, disability which prevents them from fulfilling the normal role (in the context of age, sex, and cultural factors) for the person concerned.(Sugiono, 2014, 21)

In Law Number 39 of 1999 on the Human Rights, Persons with Disabilities are categorized as vulnerable groups of people entitled to treatment and protection because of their condition. In Law Number 11 of 2009 on the Social Welfare, it is emphasized that Persons with Disabilities are classified as part of a community that has a life that is not humanly feasible and has criteria for social problems. 
Another provision that uses the term "Persons with Disabilities" is the Decree of the Minister of Health Number 378/Menkes/SK/IV/2008 on the Guidelines for Medical Rehabilitation Services at the Hospital with the term disability. The Health Minister's Decision referred to abnormalities or (impairment) is the condition where loss or abnormality of structure or function of organs or the person's system which is anatomical, physiological or psychological happen permanent or temporarily. Furthermore, it is stipulated that disability is a condition of a person's limitations or lack of ability due to impairment to carry out activities by means of fiber boundaries that are considered normal for everyone according to their age and sex. Meanwhile the handicap is a condition of a person's inability due to the presence of impairment or with disabilities that limit them in fulfilling their normal roles according to age, gender, and social and cultural factors.

Persons with disabilities are also entitled toget jobs according to their level of disability.Article 67 of Law Number 13of 2003states that employers employing personswithdisabilitiesmustprovideprotection according to their levelof disability.Althoughitis regulatedinthelaw,persons with disabilities is still often get discriminative treatmentfrom companies during the recruitment and even at work.

The research done by Economic and Social Research Institute (LPEM) Faculty of Economics and Business (FEB), University of Indonesia at the end of 2016, showed that the problems of persons with disabilities in employment, as follows:

a. The payment model of work tends to not in the form of a fixed salary, but instead a daily, weekly, orpayment based on the output produced. This shows the income instability of persons with disabilities.

b. Many do not get insurance protection and various facilities from their work places, such as health and accident insurance, and retirement.

c. People with disabilities generally work fewer hours than non-disabled people, as well as lower average hourly wages. This low wage is thought to make persons with disabilities seek additional employment.

The higher the level of education of persons with disabilities is indeed to increase wages and employment opportunities, but the increase in wages earned because of higher education is not comparable to what happens to non-disabled people. This shows the low value of education investment for persons with disabilities.(http://www.ilo.org/wcmsp5/groups/public/---asia/---ro bangkok/ ilojakarta/documents/publication/wcms_233426.pdf 
These generallyillustrates that persons with disabilities have not received proper treatmentandstillsuffer discrimination in the employment sector.

The results of $L P E M F E B$ UI research showed the level of inactivity of persons with disabilities (20.49\%) higher than non-disabled people (1.73\%), and much higher for persons with severe disabilities (57.47\%). The high percentage of persons with disabilities who do not enter the labor market is because many of them are not enthusiastic enough to enter the labor market (discourage workers), characterized by high levels of inactivity.

The population growth of persons with disabilities has increased every year. Recorded in 2010 the number of persons with disabilities was 11.58 million (Pusdatin,2010). The results of the 2017 National Work Force Unit Survey (Sakernas) show that the population of persons with disabilities has almost tripled compared to 2010, reaching 32.60 million. (Riski Wicaksono, https://www. theindonesianinstitute.com/diskriminasi-hak-kesempatan-kerja penyandangdisabilitas/)(Based on research results done by Body Centre Statistics $(B P S)$ in National Work Force Survey (Sakernas) as of February 2017, the total of persons with disabilities with productive age is $21,930,529$ people, which includes the workforce of 11,224,673 people. The work force of persons with disabilities working reach $10,810,451$ people $(96,31 \%$ ) and 414,222 people unemployed (3,69\%).(http://www.hukumonline.com/berita/baca/ lt598ac9f9b40fa/perusahaan-perlu-perluas-kesempatan-kerja penyandangdisabilitas--begini-alasannya)

The basic research of the two institutions illustrates the high number of persons with disabilities who have not been included in employment,especially the formal sector. Thus it could be known that the right of person disability to work has not been well applied.

\section{Anti-Discrimination Principle in Employment Regulation in Indonesia}

The principleaccording to the Indonesian dictionary (KBBI) onlineistheprincipleortruthwhich is the basic subject of thinking oracting. (https://artikbbi.com/prinsip) Principle can be understood in two concepts that could be combined, namely truth or righteousnessin thinkingor acting. Each activity of thought or action should be based on the truth. In order for truth to be a principle or base, it must be used as abasis for thinking or the foundation of other actions. (Lalu Husni, 2010:107) Thus relating to the right to work for persons with disabilities, both the regulation and its implementation must be based on the basis of thinking and the truth of anti-discrimination. 
Persons with disabilities in international law is included as a part of vulnerable groups. According to international provisions, vulnerable groups are, refugees, internally displaced persons (IDPS), national minorities, migrant workers, indigenous peoples, children, and women (Djohanjah, 2010). While Article 5 paragraph (3) Law Number 39 of 1999 explains that the reference set of vulnerable groups include persons with disabilities. The difference is that in international law there is clear mention of vulnerable groups, whereas in Law Number 39 of 1999 the word "among them" means there are other vulnerable groups other than those listed.

Persons with disabilities have the right to special treatment. This statement is in line with Article $28 \mathrm{H}$ paragraph (2) of the 1945 Constitution. This article regulates the right to get special facilities and treatment. These special facilities and treatment are useful for obtaining opportunities and benefits to achieve equality and justice.

Furthermore, in Article 41 paragraph (2) of Law Number 39 of 1999 it is stipulated that every person with disabilities has the right to obtain special facilities and treatment. The convenience and special treatment in this case is the provision of services, or the provision of facilities and infrastructure smoothly, securely, and safely. In Article 42 Law Number 39 of 1999 affirms that every citizen who is physically and mentally handicapped has the right to receive care, education, training and special assistance or state fees, to ensure a decent life in accordance with the dignity of their humanity. This right is also intended to increase self-confidence, and the ability to participate in community, national and state life. The provisions of this article provide a basis for the state for affirmative action. The existence of affirmative action aims as temporary assistance for other poor and vulnerable people to be able to gain access to justice.

Regarding the employment sector, arrangements for employment opportunities for persons with disabilities are regulated in various regulations. The first rule is Article 27 paragraph (2) of the 1945 Constitution which states that each citizen has the right to work and livelihood that is appropriate for humanity. This arrangement is reaffirmed in Article 28D of the 1945 Constitution which stipulates that everyone has the right to work and get fair and proper rewards and treatment in work relations. The two articles show that the 1945 Constitution guarantees the right of everyone to get equal opportunities to work according to their abilities without discrimination.(Rizano, 2014:2)

Article 38 of Law Number 39 of 1999 stipulates that every citizenis entitled to get decent job, according to their talent, skills, and abilities. 
Each person is also entitled to freely choose a job they like and has the right over the terms of fair employment. For work that is equal, comparable or commensurate, both men and women have the right to get the same wages and the terms of the same work agreement, doing work that is equal with the dignity of humanity, and are entitled to fair wages in accordance with their achievements and can guarantee the sustainability of their family lives.

The provisions in Article 27 paragraph (2), 28D and H paragraph (2) of the 1945 Constitution and Article 38 of Law Number 39 of 1999 provide an anti-discrimination basis in the field of employment for all people. This includes those with disabilities. Thus persons with disabilities in Indonesia are entitled to decent jobs for humanity as well as other Indonesian citizens who do not have a disability.(Suparman Marzuki, 2011:431-432)

In Article 5 of Law Number 13 of 2003 it is stipulated that every work force has equal opportunity without discrimination to obtain employment. Furthermore, in Article 6 of Law Number 13 of 2003 it is regulated that every worker or employee has the right to receive equal treatment without discrimination from employers. The contents of Article 5 and Article 6 of Law Number 13 of 2013 apply to all Indonesian citizens without exception. This means that these provisions also apply to persons with disabilities in Indonesia. It can be analogized that according to this provision every person with disabilities has equal opportunity without discrimination to get a job. Furthermore, it can be analogized that every worker or employee with a disability has the right to receive equal treatment without discrimination from employers. This provision is in accordance with the principle of equality before the law.

In line with the employment opportunities stipulated in Articles 5 and 6 of Law Number 13 of 2003, Article 19 of Law Number 13 of 2003 also regulates job training for workers with disabilities. This training is carried out by taking into account the type, degree of disability, and ability of the workforce of persons with disabilities concerned. Regulations concerning the right to work for persons with disabilities are also specifically regulated in several articles of Law Number 13 of 2003. The first provision is in the original Article 67 of Law Number 13 of 2003. In general, the article regulates employers that employ workers with disabilities must provide protection in accordance with the type and the degree of disability. The provision of protection is carried out in accordance with applicable laws and regulations. Furthermore Article 187 paragraph (1) of Law Number 13 of 2003 stipulates that anyone who violates the provisions of Article 67 paragraph (1) is subject to a minimum criminal sanction of 1 (one) month and 
a maximum of 12 (twelve) months and/or a minimum fine IDR 10,000,000.00 (ten million rupiahs) and at most IDR 100,000,000.00 (one hundred million rupiahs). This crime is a criminal offense.

The two articles in Law Number 13 of 2003 show that the State is trying to provide legal protection for workers with disabilities in Indonesia. The statetries to provide protection for the rights of persons with disabilities so that they are not harmed and can enjoy all the rights given by law in relation to opportunities for employment. The safeguards aim to ensure legal certainty so that the rights of workers with disabilities are not violated. In this case employers, may be subject to sanctions.

In Article 27 of Law Number 19 of 2011 confirmed that the states parties are recognizing the right of persons with disabilities to work, on an equal basis with others. The right and opportunity include the right to gain a living by freely choosing work or accept the exchange of work in an open, inclusive, and accessible work environment for persons with disabilities. States parties must protect and promote the fulfillment of the right to work, including for persons with disabilities as a result of their work by taking certain steps. These steps can be taken through legislation, among others:

a. Prohibiting discrimination on the basis of disability in all forms of work, including conditions for hiring, receiving and giving work, extending the period of employment, developing careers and working conditions that are safe and healthy;

b. Protect the rights of persons with disabilities, on an equal basis with others, to obtain fair and favorable working conditions, including opportunities and remuneration for work of equal value, healthy and safe working conditions, including protection from harassment and reduction of sadness;

c. Ensure that persons with disabilities can exercise their right to associate on an equal basis with others;

d. Enabling persons with disabilities to have effective access to guidance programs, general technical expertise and skills, placement services and expertise, as well as skills training and sustainability;

e. Promote job opportunities and career development for persons with disabilities in the workforce, such as assistance in finding, obtaining, maintaining and returning to work;

f. Promote the opportunity to have their own employment, entrepreneurship, cooperative development, and start their own business; 
g. Employing persons with disabilities in the government sector;

h. Promote the provision of employment for persons with disabilities in the private sector through appropriate policies and steps that can include concrete, intensive action programs and other measures;

i. Ensure that reasonable accommodation is available at workplaces forpersons with disabilities;

j. Promote increased work experience for persons with disabilities in open job market;

k. Increase expertise and professional rehabilitation, job security and work return programs for persons with disabilities;

States parties must also ensure that persons with disabilities are not in an enslaved condition or treated as servant. Persons with disabilities must be protected, on an equal basis with others from forced or compulsory labor.

In Article 1 number 2 of Law Number 8of2016 the equal opportunity is described asa situation that provides opportunities and/or provides access to persons with disabilitiesto channel potential in all aspects of the administration of the state and society.Furthermore Article 11 of Law Number 8 of 2016 regulates the right to work, entrepreneurship, and cooperatives for persons with disabilities. This right includes:

a. Getting a job held by the government, local government, or private sector without discrimination;

b. Get the same salary as workers who are not disabled in the same type of work and responsibility;

c. Obtain decent accommodation at work;

d. Not dismissed for reasons of disability;

e. Getting the back to work program, namely a series of procedures for handling work accident cases and work-related illnesses through health services, rehabilitation, and training so that workers can return to work;

f. Fair, proportional and dignified work placement;

Regarding employment opportunities for persons with disabilities, Article 53 of Law Number 8 of 2016 stipulates that the Government, Regional Government, State-Owned Enterprises and Regionally-Owned Enterprises must employ at least 2\% (two percent) of persons with disabilities from the number of employees or workers. Private companies must employ at least $1 \%$ (one percent) of persons with disabilities from the number of employees or workers. 
Article 54 of Law Number 8 of 2016 stipulates that the Government and Regional Government must provide incentives to private companies that employ persons with disabilities. Furthermore Article 139 of Law Number 8 of 2017 stipulates that the Government and Regional Government can give awards to legal entities and state institutions that employ persons with disabilities.

The three articles above are Article 53, Article 54, and Article 139 of Law Number 8 of 2016 intending to fulfill the principle of equality before the law. This is in accordance with Article 3 of Law Number 39 of 1999 on the Human Rights. In the article it is stipulated that everyone has the right to get recognition, be guaranteed, get protection and fair legal treatment and to obtain legal certainty and equal treatment before the law. This principle also applies to the provision of employment opportunities for persons with disabilities.

In addition to equality before the law, other principles fulfilled in the provisions of the three articles are anti-discrimination. In relation to the fulfillment of the principle of anti-discrimination for employment opportunities for persons with disabilities in Article 53, Article 54 and Article 139 of Law Number 8 of 2016 it appears that there is a quota stipulation followed by giving rewards to entrepreneurs who run it.

Regarding the right to work, the regulation in Article 5 of Law Number 13 of 2003 is a general arrangement. Aimed at all people as legal subjects. Article 5 of Law Number 13 of 2003 is an article that contains the principle of anti- discrimination. From the article it can also be interpreted that persons with disabilities have the right to work.

In contrast to Article 11 of Law Number 8 of 2016 which is more assertive and specifically regulates the rights of workers with disabilities to obtain employment. Although they both contain the principle of antidiscrimination, but Article 11 of Law Number 8 of 2016 provides clearer and more explicit rules. Article 11 of Law Number 8 of 2016 has determined who is obliged to fulfill its provisions. Likewise, the regulation in Article 27 of Law Number 19 of 2011 compared to Law Number 13 of 2003, Law Number 19 of 2011 more specifically regulates employment rights for persons with disabilities, although both adhere to the principle of antidiscrimination.

Regarding rules about recruitment, hiring, job training, work placement, work continuity, and career development of both provisions, namely Article 19 of Law Number 13 of 2003 and Article 45 of Law Number 8 of 2016 adhering to the principle of anti-discrimination.But in Article 19 of Law 
Number 13 of 2003 it is only stated in the training process and only applies between fellow persons with disabilities. This can be seen in the sentence "work training for workers with disabilities is carried out by taking into account the type, degree of disability, and the ability of the workforce of persons with disabilities concerned".

Meanwhile in Article 45 of Law Number 8 of 2016 the anti-discrimination principle applied is applied objectively. This means that not only it provides protection when workers with disabilities are dealing with fellow persons with disabilities but also for persons with disabilities when dealing with non-disabled people. This anti-discrimination principle is guaranteed from the recruitment process to career development.

Regulations regarding employment rights for persons with disabilities in both laws, namely Law Number 13 of 2003 and Law Number 8 of 2016 are in principle the same. Only in Law Number 8 of 2016 is more assertive in including the principle of anti-discrimination between workers with disabilities and non-disabled workers in the same position and type of work.

In Article 1 paragraph (3) of the 1945 Constitution Fourth Amendments it is mentioned that Indonesia is a country of law. The provisions of the article constitute the constitutional basis that Indonesia is a country based on law. In addition, the statement that the State of Indonesia is a state of law can also be seen in the explanation of the 1945 Constitution before the change.In the explanation of the 1945 Constitution before the changewas stated, there were sevenkey points of the Indonesian State government system, namely Indonesia was a country based on law (rechtstaat) and not based on mere power (maachtstaat).

Based on this explanation, the law is the order of national life all in the fields of politics, economics, socio-culture, and defenseand security in Indonesia. This means that Indonesia must recognize and protect the human rights in Indonesia.

Consequently the State must protect the human rights of its citizens. This can be done by legalizing it through legal instruments ranging from the highest, namely the constitution to the lowest. In this case, the State is also obliged to protect the human rights of persons with disabilities to be able to live properly as other citizens.

Article 71 of LawNumber 39 of 1999 stated that the government is obliged to respect, protect, uphold and promote human rights. One of them is the rights of persons with disabilities. Attempts to raise person with disabilities social welfare based on Pancasila and the 1945 Constitution is aiming to achieve 
independence and well-being of persons with disabilities (International Covenant on Civil and Political Rights).

Government's obligations and responsibilities stated in Article 72 of Law Number 39 of 1999, include effective implementation steps. This step must be carried out in various fields oflife. Efforts to provide legal protection for persons with disabilities' position, rights, obligations, and their role, especially employment sector in addition to Law Number 3 of 2013, have also been carried out through Law Number 19 of 2011 and Law Number 8 of 2016.

In substance, the law that guarantees the rights ofpersons withdisabilitiesina number of laws and regulations in Indonesia is sufficient. The formulation used in the labor laws and regulations for persons with disabilities is apositiveformulation, which is toplacethegovernment'sobligation to provide protection. Violations of these obligations are threatened with sanctions, both criminal sanctions and administrative sanctions.

According to the aspects of the structure and legal culture, there are still many provisions of the legislation that can't be implemented. This is because it has not fully fulfilled the rights ofpersons withdisabilities, especially in the field of employment. Inthiscondition, affirmative actionisneeded to realize equal opportunities in all aspects of life and livelihood for persons with disabilities. (International Covenant on Civil and Political Rights)

Thus the rights of persons with disabilities in the employment sector are included as human rights. This is in accordance with Gustav Radbruch'sopinion on regulative and constitutive functions of a constitution. The norms and principles contained in the 1945 Constitutionmust beaccommodated in the legislation below them. The norms and principlesinthe 1945 Constitution have two functions. The first function is the guiding norm or guide for positive law to achieve the ideals of protecting the rights of persons with disabilities. The second function is the norm of law examiners or positive law is in harmony with the spirit of the human rights of persons with disabilities. It means that the principle of antidiscrimination in the employment sector for persons with disabilities must also be followed by legislation under the 1945 Constitution.

\section{CLOSING}

\section{Conclusion}

The anti-discrimination principle has been adopted in various articles on legislative regulations governing the employment sector for persons with

\footnotetext{
\begin{tabular}{ll|l}
\hline Yustisia Volume 8 Number 1 (January-April 2019) $\quad$ Anti-discrimination Inemployment ... & $\mathbf{1 4 5}$
\end{tabular}
} 
disabilities, namely Law Number 3 of 2013, Law Number 19 of 2011 and Law Number 8 of 2016. If the principle in those regulations can function as a director or guide, then the aspirations to protect the human rights of persons with disabilities in the labor market can be achieved. The need for the many provisions of labor laws that have not been implemented requires affirmative action to realize equal opportunities in all aspects of life and livelihood for persons with disabilities.

\section{Suggestion}

a. The principle of anti-discrimination in the employment sector for persons with disabilities needs to be understood by the parties in labor relations in order to be able to implementlabor rights provisions without ignoring the principle of anti-discrimination for persons with disabilities.

b. Adjustments need to be made between Law Number 13 of 2003 with Law Number 19 of 2011 and Law Number 8 of 2016.

\section{BIBLIOGRAPHY:}

\section{Books:}

Marzuki, Suparman, 2011, Tragedi Politik Hukum HAM (The Tragedy of The Politics of the Law on Human Rights), Pusham UII-Pustaka Pelajar: Yogyakarta.

Palupi, Sri, 2008, Problem dan Tantangan dalam Akses Hak Ekonomi, Sosial dan Budaya (Problems and challenges in access to Economic, social and cultural , Jakarta: Komnas HAM,

Smith, Rhona K.M, 2008, Hukum Hak Asasi Manusia (Human Rights Law), Yogyakarta: PUSHAM UII

\section{Journal:}

Jazim Hamidi, (2016), Perlindungan Hukum terhadap Disabilitas dalam Memenuhi Hak Mendapatkan Pendidikan dan Pekerjaan, Journal of Law: Ius Quia Iustum, Volume 23, Number 4.

Nurjannah S, (2013), Prinsip Anti Diskriminasi Dan Perlindungan Hak-Hak Maternal Pekerja Perempuan Dalam Perspektif Keadilan, IuS Journal Volume I Number 1 April 2013, p. 33

Rizano, (2014), Implementasi Pemenuhan Hak Penyandang Cacat Dalam Memperoleh Pekerjaan Pada Perusahaan Negara Dan Swasta di Kota Pekanbaru Berdasarkan Undang-Undang Nomor 4 Tahun 1997 Tentang 
Penyandang Cacat, Online Journal of Riau Law Student, Volume I Number 2 October 2014

Sugiono, Ilhamuddin, dan Arief Rahmawan, (2014), Klasterisasi Mahasiswa Difabel Indonesia Berdasarkan Background Histories dan Studying Performance, Indonesia Journal of Disability Studies.

\section{Regulations:}

1945 Constitution of the Republic of Indonesia

Law Number 39 of 1999 on the Human Rights(State Gazette of The Republic of Indonesia Number 165 of 1999)

Law Number 13 of 2003 on the Labor (State Gazette of The Republic of Indonesia Number 39 of 2003)

Law Number 12 of 2005 on Ratification of the International Covenant on Civil and Political Rights (State Gazette of The Republic of Indonesia Number 119 of 2005)

Law Number 19 of 2011 on The Ratification of the Convention on the Right of Persons with Disabilities (State Gazette of The Republic of Indonesia Number 117 of 2011)

Law Number 8 of 2016 on The Persons with Disabilities (State Gazette of The Republic of Indonesia Number 69 of 2016)

\section{Papers:}

Monitoring The Convention on the Rights of Persons with Disabilities, Guidance for Human Rights Monitors-Professional Training Series Number 17

Djohanjah, Access On Justice, Paper on Human Rights Training for Judicial Commission Level, Bandung, July 3, 2010

Lalu Husni, Hukum Penempatan dan Perlindungan TKI, Postgraduate Program in Brawaijaya University Malang: Malang, January 2010.

PaulusE.Lotulung,TowardsSystemLawof the NationalProPersons withDisabilities, Prospectand the Challenge. Jakarta, Papers without publication year.

\section{Website:}

Persons with Disabilities Inclusion in Indonesia http://www.ilo.org/wcmsp5/ groups/public/---asia/---ro-bangkok/---ilojakarta/documents/publication/ wcms_233426.pdf

downloaded on 13 February on 16.22 WIB

\begin{tabular}{ll|l}
\hline Yustisia Volume 8 Number 1 (January-April 2019) $\quad$ Anti-discrimination Inemployment ... & $\mathbf{1 4 7}$
\end{tabular} 
InternationalLabor Organization,Persons with Disabilities Inclusion in Indonesia http:// www.ilo.org/wcmsp5/groups/public/---asia/---ro-bangkok/ilojakarta/ documents/publication/wcms_233426.pdf downloaded on February 1316.22 WIB

Riski Wicaksono, Economic Researcher on The Indonesian Institute, riski@ theindonesianinstitute.com https://www.theindonesianinstitute.com/ diskriminasi-hak-kesempatan-kerja-penyandang-disabilitas/accessed Friday, April 26, 2019, at 12.28 WIB

http://www.hukumonline.com/berita/baca/lt598ac9f9b40fa/perusahaanperlu-peringkat-kesempatan-kerjapenyandang-disabilitas--beginialasannyaaccessed Tuesday, September 5, 2018, at 20.27 WIB 